\title{
Efficacy of Different Gingival Displacement Materials in the Management of Gingival Sulcus Width: A Comparative Study
}

\author{
Aradhana Rathod ${ }^{1}$, Sonia S Jacob ${ }^{2}$, Ali MAlqahtani ${ }^{3}$, Iris Valsan ${ }^{4}$, Rizleena Majeed ${ }^{5}$, Arya Premnath ${ }^{6}$
}

\begin{abstract}
Aim: The aim of this study was to assess the effectiveness of different gingival displacement materials in the management of the width of the gingival sulcus.

Materials and methods: Totally, 60 participants who were aged 18 years and more were chosen for this study. The eligible participants were those who required fixed prosthesis with at least one abutment. A modified sectional tray was used to make impressions with elastomeric materials along with additional polysilicon using the double mix single impression technique. All participants were divided randomly into three experimental groups with each group having 20 participants as follows: group I-Expasyl, group II-Magic Foam Cord, and group IIITraxodent. Soon after retraction, impressions were made and assessed in a comparable manner to pre-retraction impressions. Image analysis software was used to measure the quantity of displacement of the gingiva, marked as the distance from the tooth to the gingival crest in the horizontal level under stereomicroscope.

Results: The highest mean sulcular gingival width $(0.644 \pm 0.22)$ was found in Traxodent group followed by Expasyl group $(0.590 \pm 0.11)$ and Magic Foam Cord group $(0.528 \pm 0.01)$. A statistically significant difference $(p<0.001)$ was found between the groups. Intergroup comparisons between the gingival displacement materials showed a statistically significant difference $(p<0.05)$ between group II and group III.

Conclusion: The present study concluded that all three gingival displacement materials lead to gingival displacement, which is needed for impression making. Slightly more retraction was seen in the Traxodent group when compared to the Expasyl group and Magic Foam Cord group. Clinical significance: The success of fixed prosthodontic treatment depends upon precision and accuracy in every step involved in the procedure. One of the most vital stepsis making precise impressions in relation to dimensional accuracy, tear strength, etc. It is essential to have an adequate thickness of the impression material along the margins to avoid distortion. This objective can be achieved by acceptable gingival retraction.

Keywords: Expasyl, Gingival displacement, Horizontal displacement, Magic Foam Cord, Traxodent.

The Journal of Contemporary Dental Practice (2021): 10.5005/jp-journals-10024-3112
\end{abstract}

\section{INTRODUCTION}

The enduring success of fixed prosthodontic restorations is mainly reliant on the well-being and firmness of the adjacent periodontal structures. Not any single restoration in dentistry is neither reliant on nor influences the periodontal health as much as the complete coverage restoration does. The complete coverage restorations frequently need margins along subgingival areas due to caries, esthetic requirements, restorations that are already present, or as a prerequisite for more retention. In these scenarios, the dentist must make impressions that precisely capture the cervical finish lines prepared intraorally, fabricate exact dies, over which restorations are made.'

In order to make an accurate impression, it is vital to have a dry (free of fluid) and clean (free of debris) field intraorally, and the subgingival tissue has to be pushed to record the finish line. The finish lines and prepared abutments can be accurately registered by active gingival retraction, that is, displacement of gingival tissue to expose the cervical part of the tooth surface. ${ }^{2}$

Gingival tissues get displaced reversibly with gingival retraction such that most of the impression material with low viscosity can enter the enlarged sulcus and capture the margins. Both vertical and lateral displacement of gingival tissues can be obtained with gingival retraction. With vertical retraction, the cut part of the tooth apical to the finish linegets exposed. Lateral retraction shifts the tissues and offers acceptable bulk of impression material such that it could be removed intact from the mouth without any tears. ${ }^{3}$
${ }^{1}$ Department of Prosthodontics, Al-Badar Rural Dental College and Hospital, Kalaburgi, Karnataka, India

${ }^{2}$ Department of Prosthodontics, Azeezia Dental College, Kollam, Kerala, India

${ }^{3}$ College of Dentistry, Prince Sattam Bin Abduaziz University, Al-Kharj, Saudi Arabia

${ }^{4}$ Department of Public Health Dentistry, Government Dental College, Thrissur, Kerala, India

${ }^{5}$ Department of Periodontology, Kannur Dental College, Kannur, Kerala, India

${ }^{6}$ Department of Periodontics, Sree Anjaneya Institute of Dental Sciences, Kozhikode, Kerala, India

Corresponding Author:Aradhana Rathod, Department of Prosthodontics, Al-Badar Rural Dental College and Hospital, Kalaburgi, Karnataka, India, Phone:+919448022262, e-mail: draprathod@gmail.com

How to cite this article: Rathod A, Jacob SS, MAlqahtani A, et al. Efficacy of Different Gingival Displacement Materials in the Management of Gingival Sulcus Width: A Comparative Study. J Contemp Dent Pract 2021;22(6):703-706.

Source of support: Nil

Conflict of interest: None

The market presently has numerousoptionsfor gingival tissue retraction, for example, surgical method (rotary curettage, electrosurgery, and lasers), mechanical method (retraction cords),

( ) Jaypee Brothers Medical Publishers. 2021 Open Access This article is distributed under the terms of the Creative Commons Attribution 4.0 International License (https://creativecommons.org/licenses/by-nc/4.0/), which permits unrestricted use, distribution, and non-commercial reproduction in any medium, provided you give appropriate credit to the original author(s) and the source, provide a link to the Creative Commons license, and indicate if changes were made. The Creative Commons Public Domain Dedication waiver (http://creativecommons.org/publicdomain/zero/1.0/) applies to the data made available in this article, unless otherwise stated. 
and chemo-mechanical method (chemicals embedded in cords). The most common being the use of gingival retraction cords. ${ }^{4}$

The cordless methods have now been presented with many claimed benefits, such as negligibly invasive, time-saving, and improved patient comfort. There are clinical reports regarding the use of this displacement material, but the effectiveness of the tissue displacement achieved is not adequately documented. Expasyl is a gingival retraction material with paste-like consistency, which is reliant on the hygroscopic expansion of kaolin on contacting the crevicular fluid and hemostatic properties of aluminum chloride, to provide minor gingival displacement within 2 minutes. Magic Foam Cords is a polyvinyl siloxane material that gradually expands and is fabricated for simple and quick sulcular gingival retraction with no time-consuming and potentially traumatic episodes of packing of retraction cord. ${ }^{5}$

The recently introduced Traxodent Hemodent paste retraction material is made up of $15 \%$ aluminum chloride topical paste and cotton caps and has been fabricated to enhance the gingival displacement and aid in hemostasis. ${ }^{6}$ Thus, this study was conducted to evaluate the effectiveness of diverse gingival displacement materials in the management of the width of the gingival sulcus.

\section{Materials and Methods}

\section{Selection Criteria}

The present study was conducted in the Department of Prosthodontics. Totally, 60 participants aged 18 years and more were chosenfor this study. The eligible participants were those who required fixed prosthesis with at least one abutment. Ethical approval was obtained (ADCH/2018/06/0172), and all the participants provided written informed consent.

Participants needing fixed prosthetic treatment with at least one abutment tooth, age at least 18 years, having a healthy abutment toothclinically and radiographically, with no regressive changes or development anomaly, with a probing depth of $<3 \mathrm{~mm}$ were included in this study.

Patients aged $<18$ years with uncontrolled diabetes, hypertension, hyperthyroidism, and other cardiovascular disorders, abutment tooth with signs of attachment loss and clinical mobility, and the presence of exudates were excluded from this study.

\section{Pre-retraction Impression}

Prior to the initiation of crown preparation, alginate impressions were made for the chosen arch to fabricate a customized sectional tray for elastomeric impression making. Post this, the crown was prepared witha finish line positioned equigingivally. After this, an elastomeric impression was made using a double mix single impression technique with a customized sectional tray with the help of additional polysilicon. The impression was verified for the presence of any voids, after which it was boxed and then poured in type IV dental stone.

Later a flexible, smooth measuring strip with gradings of $0.5 \mathrm{~mm}$ was used to measure the depth of sulcus at midbuccal, distobuccal, and mesiobuccal regionsin the vertical direction prior to retraction. Post this, the gingiva surrounding the abutment tooth was retracted with the help of either of the gingival displacement materials.

\section{Sample Size Calculation}

The formula used to calculate sample size was

$$
n=\frac{Z_{1-\alpha / 2}^{2}}{d^{2}}
$$

where

$n$ is the required sample size

$z_{1-\alpha / 2}$ is a constant, and its value for a two-sided test is 1.96 for $95 \%$

$d$ is absolute precision $20 \%=0.2$

$\sigma$ is pooled variance

All 60 participants were divided randomly into three investigational groups, that is, 20 participants in each group as follows (Fig. 1).

\section{Group I: Expasyl}

A gun at even pressure was used to inject the Expasyl (Kerr Corp., Orange, California, USA) retraction paste slowly into the gingival sulcus. The tip of the gun was perpendicular to the tooth axis, and then it was pressed toward the tooth and positioned until it touched the sulcus lining of the gingival margin. Expasyl was retained in position for 2 minutes. The tooth was then profusely irrigated with water until all remnants of materials are washed away. ${ }^{7}$
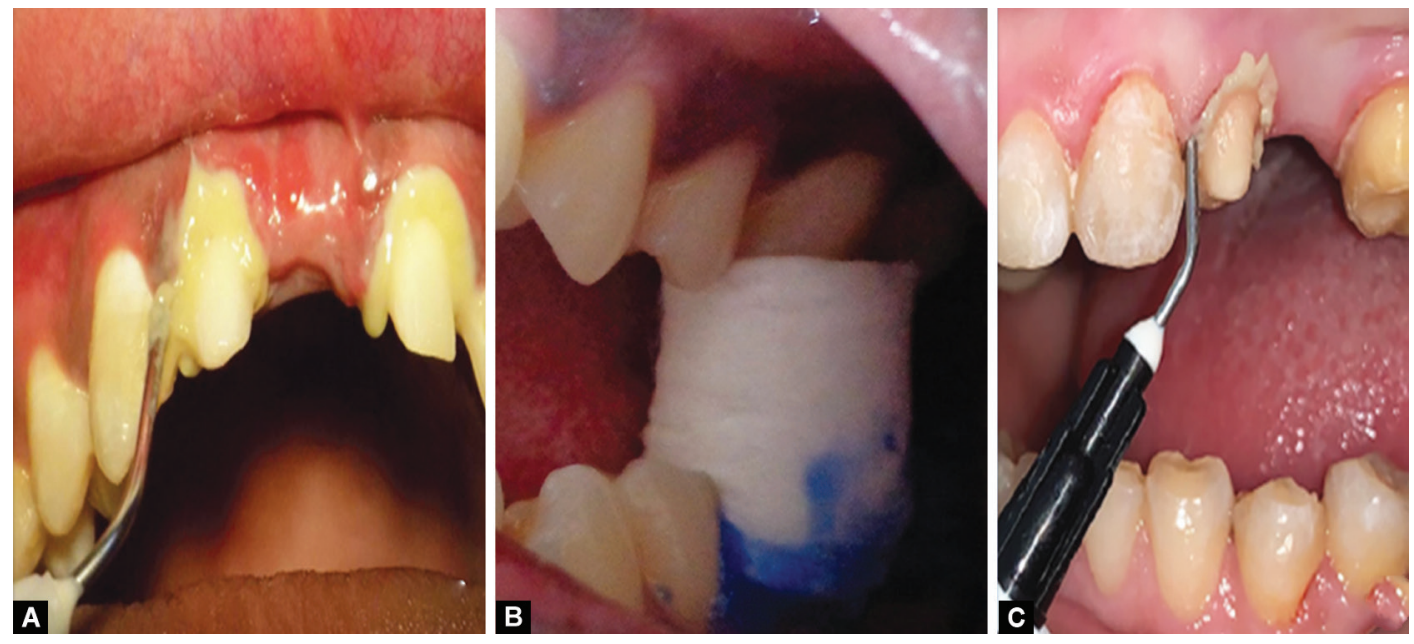

Figs $1 \mathrm{~A}$ to C: Application of gingival displacement materials (A) Expasyl; (B) Magic Foam Cord; (C) Traxodent 


\section{Group II: Magic Foam Cord}

Magic Foam Cord (ColteneWaldent AG, Altstatten, Switzerland) is a mechanical method of gingival retraction with no medicaments. The Magic Foam Cord was held in position during the retraction technique with the help of Comprecap, which was manufacturerprovided. The suitable size of Comprecap was chosen and altered. Magic Foam Cord was injected into the sulcus of the gingiva. The chosen Comprecap was held on to the abutment to push the material deep into the sulcus of the gingiva, and the participants were informed to bite over it for a period of 3 to 5 minutes. ${ }^{3}$

\section{Group III: Traxodent}

The margins of prepared teeth were held dry by air-drying. A syringe was used to dispense the Traxodent (Premier Dental, Pennsylvania, USA) paste into the sulcus of gingiva. The paste was then gradually applied all around the sulcus of the teeth. The gingival had to turn white to indicate that the paste was applied well. As per the manufacturer's suggestions, the paste was left there for 2 minutes and then rinsed off with water. After this, the tooth was air-dried. ${ }^{6}$

Soon after this, post-retraction impressions were made and assessed in a comparable manner to pre-retraction impressions. The impressions were made to a cast with type IV dental stone using a vacuum mixer and vibrator. Once the material was set, the casts were regained and trimmed to get a flat base.

\section{Measurement of Gingival Displacement}

An image analysis software was used to measure the quantity of displacement of gingiva, marked as the distance from the tooth to the gingival crest in the horizontal level under a stereomicroscope (SZMCTV1/2 Spectro). The image analysis measurements were recorded in a micrometer scale, which was then converted into grading in millimeters. The amount of retraction was considered by subtracting the measured width prior tothe retraction from the one which was obtained post-retraction.

\section{Statistical Analysis}

The mean and standard deviation was calculated using SPSS software (version 20.0). The comparison between different groups of gingival displacement materials was done using one-way analysis of variance. A $p$-value of less than 0.05 was measured statistically significant.

\section{Results}

The comparison of mean sulcular gingival width prior to placement of gingival displacement materials is as shown in Table 1. The highest mean sulcular gingival width $0.184 \pm 0.12$ was in Magic Foam Cord group, followed by Expasyl group $(0.180 \pm 0.20)$ and Traxodent group $(0.178 \pm 0.14)$. But no statistically significant difference was found between the groups ( $p>0.05$ ).

The comparis on of mean sulcular gingival width after placement of gingival displacement materials is as demonstrated in Table 2. The highest mean sulcular gingival width was $0.644 \pm 0.22$ in Traxodent group, followed by Expasyl group $(0.590 \pm 0.11)$ and Magic Foam Cord group $(0.528 \pm 0.01)$. A statistically significant difference $(p<0.001)$ was found between the groups.

Table 3 shows multiple comparisons between the different gingival displacement material groups. A statistically significant difference $(p<0.05)$ was found between groups II and III.
Table 1: Comparison of mean gingival sulcus width before placement of gingival displacement materials

\begin{tabular}{|c|c|c|c|}
\hline Gingival displacement materials & & & \\
\hline Groups & Mean $\pm S D$ & Fvalue & $p$ value \\
\hline Group I: Expasyl & $0.180 \pm 0.20$ & & \\
\hline Group II: Magic Foam Cord & $0.184 \pm 0.12$ & 19.084 & 0.860 \\
\hline Group III:Traxodent & $0.178 \pm 0.14$ & & \\
\hline
\end{tabular}

Table 2: Comparison of mean gingival sulcus width after placement of gingival displacement materials

Gingival displacement materials

\begin{tabular}{llll}
\hline Groups & Mean $\pm S D$ & Fvalue & pvalue \\
\hline Group I: Expasyl & $0.590 \pm 0.11$ & & \\
Group II: Magic Foam Cord & $0.528 \pm 0.01$ & 22.408 & 0.001 \\
Group III:Traxodent & $0.644 \pm 0.22$ & & \\
\hline
\end{tabular}

Table 3: Comparisons of the mean difference between the groups using Tukey Honestly Significant Difference

\begin{tabular}{llcl}
\hline Group & Compared with & Mean difference (I-J) & Sig. \\
\hline \multirow{2}{*}{ Group I } & Group II & 0.062 & 0.18 \\
& Group III & -0.054 & 0.06 \\
\multirow{2}{*}{ Group II } & Group I & -0.062 & 0.18 \\
& Group III & -0.116 & $0.001^{*}$ \\
\multirow{2}{*}{ Group III } & Group I & 0.054 & 0.06 \\
& Group II & 0.116 & $0.001^{*}$ \\
\hline
\end{tabular}

*Significant,

$p<0.05$

\section{Discussion}

Fixed prosthodontic treatment includes the use of artificial substitutes for the restoration and replacement of teeth so as to enhance patients' masticatory efficiency and comfort, preserve integrity and health of the dental arches, and elevate the patients' self-identity. The utmost basic measure of the tooth preparation principles is marginal integrity. ${ }^{8}$

The restoration's success and healthiness of the prepared abutment tooth's periodontium critically depend on anagreeable association between the finish line and gingival margins. It is desirable to position the restoration's gingival finish lines either equigingival or supragingival after consideration of periodontium's health. It becomes inevitable to place the margins subgingivally due to various reasons, such as esthetics, caries, prevailing restorations, and a necessity for extra retention. Because of these, some type of gingival displacement is required to record the finish line. ${ }^{9}$

Gingival displacement or tissue management is defined as "the refraction of marginal gingiva away from the tooth prior to recording the impressions is a critical stage for ideal replication of marginal details in fixed restorations. ${ }^{10}$ Displacement of gingiva enables efficient impression making, management of fluid, finishing and positioning of prepared tooth margins, elimination of extra cement, etc. Impressions made with the width of sulcus lesser than the ideal value,that is, 0.15 to $0.2 \mathrm{~mm}$, have increased frequencies of voids in the marginal area and reduced tear strength of impression material. ${ }^{11}$ 
In this study, the extreme increase in mean width of sulcular gingiva was found in Traxodent group followed by Expasyl group and Magic Foam Cord group. As per Phatale et al., ${ }^{12}$ it is safe and easy to use newly improved material, the retraction pastes like Expasyl or Magic Foam Cord forgingival retraction. The slightest pressure applied by Magic Foam paste on the gingiva led to hemostasis. They were found to be better than the cord histologically, with regards to the periodontium. The tolerance by the patient was noted to be very good. The material demonstrated complete biocompatibility without the requirement of anesthesia. It was also reinforced by Kazemi et al. ${ }^{13}$ that retraction paste causes reduced gingival inflammation.

It was reported by Raghav et al. ${ }^{14}$ that MagicFoam was an expanding polyvinyl siloxane material designed for fast, easy, and atraumatic sulcular gingival displacement. However, it was found to be less efficient when compared to the other two groups. The effectiveness of three nontraumatic gingival displacement systems was evaluated by Thimmappa et al. ${ }^{15}$ and Singh et al., ${ }^{16}$ and they reported minimum gingival displacement with Magic Foam Cord. These results are in accordance with the results obtained by our study.

A single operator recorded all the measurements in this study so as to avoid the inconsistency in measurements that could arise by multiple operators. The present study results are not similar to the results obtained by Kohli and Hegde ${ }^{6}$ who reported Traxodent as a chemical method thatdid not generate physical pressure when placed in the gingival sulcus. Thus, Traxodent attained less amount of retraction. One more study by Gupta et al. ${ }^{10}$ found statistically significant differences between vertical and horizontal retraction achieved by Traxodent, and this was less.

As per the results obtained by this study, all the three retraction systems are judiciously satisfactory, because all three offer more retraction than the least amount of retraction $(0.22 \mathrm{~mm})$ needed for any fixed partial denture impressions. ${ }^{17}$ After considering the limitations of this study, it was demonstrated that the use of the paste system was quick, easy, and painless, thus minimizing chairside time.

Many more studies have to be performed in the future to analyzevarious retraction systems that are commercially available and made explicitly for fixed partial impressions. Digital techniques could be used to make measurements than manual measurements. The limitations of this study are the impact of gingival distensibility, the thickness of the gingiva, diverse sulcular depth, and failure to consider the accessibility and visibility on the gingival displacement.

\section{Conclusion}

The present study concluded that all three gingival displacement materials lead to gingival displacement that is needed for impression making. Slightly more retraction was seen in Traxodent group when compared to the Expasyl group and Magic Foam Cord group.

\section{References}

1. Rayyan MM, Hussien ANM, Sayed NM, et al. Comparison of four cordless gingival displacement systems: aclinical study. J Prosthet Dent 2019;121(2):265-270.DOI: 10.1016/j.prosdent.2018.05.010.

2. Koth DL. Full crown restorations and gingival inflammation in a controlled population. J Prosthet Dent 1982;48(6):681-685. DOI: 10.1016/s0022-3913(82)80028-0.

3. Sachdev PA, Arora A, Nanda S. A comparative evaluation of different gingival retraction methods: an in vivo study. Oral Health Case Rep 2018;4:142.DOI: 10.4172/2471-8726.1000142.

4. Bennani V, Inger M, John M. Arts comparison of pressure generated by cordless gingival displacement materials. J Prosthet Dent 2014;112(2):163-167.DOI: 10.1016/j.prosdent.2013.09.035.

5. Gupta R, Aggarwal R, Siddiqui Z. Comparison of various methods of gingival retraction on gingival and Periodontal health and marginal fit. Int J Oral Health Dent 2016;2(4):243-247.DOI: 10.18231/2395499X.2016.0012.

6. Kohli PK, Hegde V. Comparative evaluation of efficacy of gingival retraction using chemical and mechanical methods: an in vivo study. Asian J Pharm Clin Res 2018;11(2):128-131.DOI:10.22159/ajpcr.2018. v11i2.22674.

7. Agarwal A, Lahori M, Arora S. A comparative evaluation of two contemporary cordless methods of gingival retraction - an in vivo study. J Interdiscip Dent2019;9(2):51-58.DOI:10.4103/jid.jid_79_18.

8. Gajbhiye V, Banerjee R, Jaiswal $P$, et al. Comparative evaluation of three gingival displacement materials for efficacy in tissue management and dimensional accuracy. J Indian Prosthodont Soc 2019;19(2):173-179.DOI: 10.4103/jips.jips_285_18.

9. Shillingburg HT, Hobo S, Whitsett LD, editors. Fundamentals of fixed prosthodontics. Chicago: Quintessence; 1997. p. 260-276.

10. Gupta A, Prithviraj DR, Gupta D, et al. Clinical evaluation of three new gingival retraction systems: aresearch report. J Indian ProsthodontSoc 2013;13(1):36-42.DOI: 10.1007/s13191-012-0140-y.

11. Smeltzer M. An alternative way to use gingival retraction paste. J Am Dent Assoc 2003;134(11):1485.DOI: 10.14219/jada. archive.2003.0078.

12. Phatale S, Marawar PP, Byakod G, et al. Effect of retraction materials on gingival health: ahistopathological study. J Indian Soc Periodontol 2010;14(1):35-39. DOI: 10.4103/0972-124X.65436.

13. Kazemi M, Memarian M, Loran V. Comparing the effectiveness of two gingival retraction procedures on gingival recession and tissue displacement: clinical study. Res J Bio Sci2009:4(3);335-339. https:// medwelljournals.com/abstract/?doi=rjbsci.2009.335.339.

14. Raghav D, Singh S, Kola MZ, et al. A comparative clinical and quantitative evaluation of the efficacy of conventional and recent gingival retraction systems: an in vitro study.EurJProsthodont2014;2(3):76-81. DOI:10.4103/2347-4610.140514.

15. Thimmappa M, Bhatia M, Somani $P$, et al. Comparative evaluation of three noninvasive gingival displacement systems: an in vivo study. J Indian ProsthodontSoc2018;18(2):122-130.DOI: 10.4103/jips. jips_225_17.

16. Singh AA, Rao BK, Gujjari AK. Evaluation of gingival displacement using foam cord and retraction cord: an in vivo study. J Int Oral Health2019;11(1):8-12. DOI: 10.4103/jioh.jioh_169_18.

17. Chaudhari J, Prajapati P, Patel J, et al. Comparative evaluation of the amount of gingival displacement produced by three different gingival retraction systems: an in vivo study. ContempClin Dent 2015;6(2):189-195.DOI: 10.4103/0976-237X.156043. 